\title{
Chronic ethanol exposure induces SK-N-SH cell apoptosis by increasing N-methyl-D-aspartic acid receptor expression and intracellular calcium
}

\author{
HONGBO WANG $^{1 *}$, XIAOLONG WANG ${ }^{1 *}$, YAN LI $^{2 *}$, HAO YU $^{1}, \mathrm{CHANGLIANG} \mathrm{WANG}^{1}, \mathrm{CHUNMEI} \mathrm{FENG}^{1}$, \\ GUOHUI XU ${ }^{1}$, JIAJUN CHEN ${ }^{1}$, JIABIN YOU ${ }^{1}$, PENGFEI WANG ${ }^{1}$, XU WU $^{1}$, RUI ZHAO $^{1}$ and GUOHUA ZHANG ${ }^{1}$ \\ ${ }^{1}$ Department of Forensic Pathology, School of Forensic Medicine, China Medical University; ${ }^{2}$ No.1 English Department, \\ School of Fundamental Sciences, China Medical University, Shenyang, Liaoning 110122, P.R. China
}

Received August 22, 2017; Accepted January 12, 2018

DOI: $10.3892 /$ etm.2018.5902

\begin{abstract}
It has been identified that chronic ethanol exposure damages the nervous system, particularly neurons. There is scientific evidence suggesting that neuronal loss caused by chronic ethanol exposure has an association with neuron apoptosis and intracellular calcium oscillation is one of the primary inducers of apoptosis. Therefore, the present study aimed to investigate the inductive effects of intracellular calcium oscillation on apoptosis in SK-N-SH human neuroblastoma cells and the protective effects of the N-methyl-D-aspartic acid receptor (NMDAR) antagonist, memantine, on SK-N-SH cell apoptosis caused by chronic ethanol exposure. SK-N-SH cells were treated with $100 \mathrm{mM}$ ethanol and memantine $(4 \mu \mathrm{M})$ for 2 days. Protein expression of NR1 was downregulated by RNA interference (RNAi). Apoptosis was detected by Annexin V/propidium iodide (PI) double-staining and flow cytometry and cell viability was detected using an MTS kit. Fluorescence dual wavelength spectrophotometry was used to determine the intracellular calcium concentration and the levels of NR1 and caspase-3 were detected using western
\end{abstract}

Correspondence to: Professor Guohua Zhang or Professor Rui Zhao, Department of Forensic Pathology, School of Forensic Medicine, China Medical University, 77 Puhe Road, Shenyang North New Area, Shenyang, Liaoning 110122, P.R. China

E-mail: ghzhang@cmu.edu.cn

E-mail:rzhao@cmu.edu.cn

*Contributed equally

Abbreviations: NMDAR, N-methyl-D-aspartic acid receptor; IP3, inositol 1, 4,5-trisphosphate; SERCA, sarco/endoplasmic reticulum calcium adenosine triphosphatase ATP; shRNA, short hairpin RNA; HBSS, Hank's balanced salt solution; PI, propidium iodide; TBS-T, Tris-buffered saline containing $0.05 \%$ Tween-20; Cq, quantification cycle

Key words: ethanol, N-methyl-D-aspartic acid receptor, intracellular calcium, apoptosis, memantine blotting. NR1 mRNA levels were also detected using qPCR. It was found that chronic ethanol exposure reduced neuronal cell viability and caused apoptosis of SK-N-SH cells, and the extent of damage in SK-N-SH cells was associated with ethanol exposure concentration and time. In addition, chronic ethanol exposure increased the concentration of intracellular calcium in SK-N-SH cells by inducing the expression of NMDAR, resulting in apoptosis, and memantine treatment reduced ethanol-induced cell apoptosis. The results of the present study indicate that the application of memantine may provide a novel strategy for the treatment of alcoholic dementia.

\section{Introduction}

Ethanol is eventually metabolized to carbon dioxide and water via a dehydrogenase and oxidase. Ethanol and a series of intermediate products in its metabolism have certain toxic effects on tissues and cells, which may result in a wide range of mental and physical abnormalities (1). Chronic alcoholism may damage multiple systems and organs including the nervous, cardiovascular, digestive and immune system, as well as muscle. In a previous study, it was demonstrated that ethanol may lead to the loss of neurons in specific brain regions (2). It has been suggested that cell necrosis or apoptosis may be activated by ethanol via a variety of mechanisms, such as enhancing expression of tumor necrosis factor- $\alpha(3,4)$ and Fas/Fas ligand $(5,6)$, inducing transcriptional activity of nuclear factor- $\kappa \mathrm{B}(7,8)$, activating caspases in mitochondria (9) and causing transport disorders of intracellular $\mathrm{Ca}^{2+}(10)$. Intracellular $\mathrm{Ca}^{2+}$ serves an important role in cell biology, which influences or determines necrosis or apoptosis independently. Cellular $\mathrm{Ca}^{2+}$ overload is the hub of necrosis or apoptosis $(11,12)$. Intracellular $\mathrm{Ca}^{2+}$ originates from L-type voltage-operated calcium channels, $\mathrm{N}$-methyl-D-aspartate receptor (NMDAR)-mediated calcium influx into cells (13), inositol 1,4,5-trisphosphate (IP3)-induced calcium release (14) and ryanodine receptor-induced calcium release (15). A previous report has identified a rise of excitatory amino acids in patients with chronic alcohol poisoning (16), such as glutamate, aspartate and homocysteine, which significantly increased the vulnerability of neurons to excitotoxicity and oxidative damage. Excitatory amino acids serve a role in 
NMDAR overstimulation, oxidative stress, caspase activation, DNA damage and mitochondrial dysfunction (17). NMDAR is a ligand-gated $\mathrm{Ca}^{2+}$ channel that is closely associated with central nervous system development, learning and memory $(18,19)$. Following chronic ethanol exposure, NMDAR in the central nervous system is more sensitive to NMDA, which is known as NMDAR hyper-excitement (20), a primary cause of ethanol withdrawal symptoms and neuronal over-excitability (21). NMDAR is heteromeric and consists of three subunits: NR1, NR2 and NR3 (22). The NR1 subunit is the functional subunit of NMDAR, which is widespread in the central nervous system of animals (23). It has been demonstrated previously that, following long-term ethanol feeding, cerebral cortical MK-801 binding in guinea pigs was significantly higher than that in a control group (24) and there appeared to be greater expression of NR1 in the cerebral cortex, hypothalamus and hippocampus of rats (25). These findings suggested that long-term ethanol exposure results in an adaptive increase in NMDAR, causing hyper-excitation of NMDAR. Preconditioning with non-competitive NMDAR antagonist, memantine and downregulation of NMDAR expression by small interfering RNA (siRNA) control intracellular $\mathrm{Ca}^{2+}$ release (26), thereby inhibiting caspase-3 activation and controlling or reducing the occurrence of neuronal apoptosis induced by isoflurane. The present study aimed to determine the role of NMDAR and intracellular calcium in ethanol-induced SK-N-SH cell apoptosis and assess the neuroprotective and therapeutic effect of memantine.

\section{Materials and methods}

Cell line. In the present study, SK-N-SH human neuroblastoma cells were purchased from Nanjing KeyGen Biotech Co., Ltd. (Nanjing, China). The cells were cultured in high glucose Dulbecco's modified Eagle's medium (DMEM; Biological Industries, Kibbutz Beit-Haemek, Israel) containing 10\% fetal bovine serum, $100 \mathrm{U} / \mathrm{ml}$ penicillin and $100 \mu \mathrm{g} / \mathrm{ml}$ streptomycin (all purchased from Biological Industries). Cells were maintained at $37^{\circ} \mathrm{C}$ in a humidified atmosphere containing $5 \% \mathrm{CO}_{2}$.

Ethanol volatilization detection. The present study determined that ethanol volatilized over time under normal culture conditions, thereby reducing the ethanol concentration in the culture medium. Therefore, ethanol volatilization was determined per $24 \mathrm{~h}$ and appropriate quantities of ethanol were added to maintain relatively stable concentrations of ethanol in the medium. $5 \mathrm{ml}$ culture medium containing ethanol $(50,100,200$ and $400 \mathrm{mM})$ was added into a $25-\mathrm{cm}^{2}$ cell culture flask. After $24 \mathrm{~h}$ at $37^{\circ} \mathrm{C}$, the remaining ethanol concentration was detected using headspace gas chromatography (cat. no. GC-14A; Shimadzu Corporation, Kyoto, Japan), as described in a previous study (27). The quantity of daily ethanol volatilization was calculated using the following equation: Quantity of daily ethanol volatilization = initial quality - remaining quality.

Grouping. SK-N-SH cells were cultured in a $25-\mathrm{cm}^{2}$ cell culture flask at a density of $1 \times 10^{6}$ cells $/ \mathrm{ml}$. Ethanol was added into DMEM culture medium at $37^{\circ} \mathrm{C}$. When cells reached an $80-90 \%$ confluence, according to the duration of ethanol treatment,
SK-N-SH cells were divided into 24, 48 and $72 \mathrm{~h}$ groups, and according to the ethanol concentration, cells were divided into 0 (control group), 50, 100, 200 and $400 \mathrm{mM}$ groups. Ethanol at 0 and $100 \mathrm{mM}$ was also used to treat SK-N-SH cells for 2 days at $37^{\circ} \mathrm{C}$ and cells were categorized into memantine (Sigma-Aldrich; Merck KGaA, Darmstadt, Germany) and non-memantine groups. The concentration of memantine used was $4 \mu \mathrm{M}$. According to whether protein expression of NR1 was downregulated by RNA interference (RNAi), cells were divided into NR1 short hairpin RNA (shRNA) and control shRNA groups.

RNAi. SK-N-SH cells were seeded in 6-well plates at a low density $(<10 \%$ confluence) in normal growth medium containing various concentrations of puromycin (cat. no. sc108071; Santa Cruz Biotechnology, Inc., Dallas, TX, USA) $(0,1,2,3,4,6,8$ and $10 \mu \mathrm{g} / \mathrm{ml}$ ) to determine the minimum concentration necessary to kill all untransfected cells. An NR1 shRNA plasmid (cat. no. sc-91941-SH; Santa Cruz Biotechnology, Inc.) was used in the RNAi. It is a pool of 3 target-specific lentiviral vector plasmids, each encoding 19-25 nucleotide (plus hairpin) shRNAs designed to knock down gene expression. The control shRNA plasmid (cat. no. sc-108060; Santa Cruz Biotechnology, Inc.) encodes a scrambled shRNA sequence that does not degrade any known cellular mRNA. The NR1 shRNA plasmid and the control shRNA plasmid were of the same vector type. Each plasmid contained a puromycin resistance gene for the selection of stable cells that express the desired shRNA. At 60-70\% confluency, shRNA Plasmid Transfection Reagent (10/200 $\mu$ l, cat. no. sc-108061; Santa Cruz Biotechnology, Inc.) was used to transfect the NR1 shRNA plasmid $(5 / 200 \mu \mathrm{l})$ and control shRNA plasmid $(5 / 200 \mu \mathrm{l})$ into cells, according to the manufacturers' protocol. Following $48 \mathrm{~h}$ transfection at $37^{\circ} \mathrm{C}$, the medium was replaced with fresh DMEM medium containing puromycin $(1 \mu \mathrm{g} / \mathrm{ml})$ to select the transfected cells over 5 days at $37^{\circ} \mathrm{C}$. At $90 \%$ confluency, total protein was extracted and the transfection efficiency was determined by western blotting. The sequences of NR1 shRNA and control shRNA (28) are presented in Table I.

MTS assay. Cell viability was determined using an MTS kit (Promega Corporation, Madison, WI, USA). SK-N-SH cells were seeded at a density of 4,000 cells/well and treated in 96-well plates for various durations. Following $24 \mathrm{~h}$ culture, the cells were washed with PBS three times and fresh DMEM medium $(100 \mu \mathrm{l})$ and MTS $(20 \mu \mathrm{l})$ reagent were added to the wells for $1 \mathrm{~h}$ at $37^{\circ} \mathrm{C}$ in the dark $(25,26)$. The absorbance was measured at a wavelength of $490 \mathrm{~nm}$ on an ELx808 absorbance reader (BioTek Instruments, Inc., Winooski, VT, USA). To eliminate possible interference by alcohol, cells treated with the same concentrations of alcohol $(0,50,100,200$ and $400 \mathrm{mM})$ and memantine $(4 \mu \mathrm{M})$ but without addition of assay reagents were used as blank controls. All experiments were repeated at least five times.

Annexin V/propidium iodide (PI) double-staining. Cell apoptosis was measured using an Annexin V-fluorescein isothiocyanate (FITC)/PI apoptosis detection kit (BD Biosciences, San Jose, CA, USA). SK-N-SH cells were seeded at a density of $1 \times 10^{6}$ cells $/ \mathrm{ml}$ and treated in $25-\mathrm{cm}^{2}$ tissue culture flasks until an 80-90\% confluence was observed. Following washing with PBS twice, cells were double-stained with FITC-conjugated Annexin V and PI 
Table I. Sequences of shRNA.

\begin{tabular}{ll} 
shRNA & \multicolumn{1}{c}{ Sequence } \\
\hline NR1 shRNA-A & \\
Hairpin sequence & 5'GATCCCCATGTTCTTAGAGAAGATTTCAAGAGAATCTTCTCTAAGAACATGGTTTTT'3 \\
Corresponding siRNA & 5'CCAUGUUCUUAGAGAAGAUtt'3
\end{tabular}

sense sequence

Corresponding siRNA

antisense sequence

5'AUCUUCUCUAAGAACAUGGtt'3

NR1 shRNA-B

Hairpin sequence

Corresponding siRNA

sense sequence

Corresponding siRNA

antisense sequence

NR1 shRNA-C

Hairpin sequence

Corresponding siRNA

sense sequence

Corresponding siRNA

antisense sequence

Control shRNA

5'GATCCCTTGTATTGTCGGGAAAGATTCAAGAGATCTTTCCCGACAATACAAGTTTTT'3
5'CUUGUAUUGUCGGGAAAGAtt'3

5'UCUUUCCCGACAAUACAAGtt'3

5'GATCCCAAGGTGGATCCAGTTTCTTTCAAGAGAAGAAACTGGATCCACCTTGTTTTT'3 5'CAAGGUGGAUCCAGUUUCUtt'3

5'AGAAACUGGAUCCACCUUGtt'3

5'TTCTCCGAACGTGTCACGTTTCAAGAGAACGTGACACGTTCGGAGAATTTTT'3

shRNA, short hairpin RNA.

for $15 \mathrm{~min}$ at $20^{\circ} \mathrm{C}$ in a $\mathrm{Ca}^{2+}$-enriched binding buffer in the kit. Cells were immediately analyzed on a flow cytometer in their staining solution. Annexin V and PI emissions were detected in the FL-1 (band pass, $530 \mathrm{~nm}$; band width, $30 \mathrm{~nm}$ ) and FL-2 (band pass, $585 \mathrm{~nm}$; band width, $42 \mathrm{~nm}$ ) channels. A total of 10,000-20,000 events were recorded per sample. BD FACSDiva V8.0.1 software (BD Biosciences) was used to analyze this data.

Intracellular calcium measurement. Intracellular $\mathrm{Ca}^{2+}$ was measured with the $\mathrm{Ca}^{2+}$-sensitive dye fura-2-acetoxymethyl ester (fura-2-AM; Dojindo Molecular Technologies, Inc., Kumamoto, Japan) as previously described (29). SK-N-SH cells were seeded to $80-90 \%$ confluence and treated in $25-\mathrm{cm}^{2}$ tissue culture flasks. To prepare cell suspensions, the cells were washed twice with Hank's balanced salt solution (HBSS; Biological Industries), trypsinized (Biological Industries), centrifuged at a speed of 2,000 x g, for $5 \mathrm{~min}$ at room temperature) and resuspended in HBSS containing $20 \mathrm{~g} / \mathrm{l}$ bovine serum albumin (Biological Industries), and the cell concentration was adjusted to $1 \times 10^{6}-1 \times 10^{7}$ cells $/ \mathrm{ml}$. The survival rate of the cells was determined using a trypan blue staining cell viability assay kit (Beyotime Institute of Biotechnology, Shanghai, China) according to the manufactures' protocol. A total of $0.1 \mathrm{ml}$ cell suspension, containing $10^{5}$ cells was mixed with $0.4 \%$ trypan blue solution $(0.1 \mathrm{ml})$. The mixture was then incubated for 3 min at room temperature. The quantity of living cells (which were not stained by trypan blue) were counted and determined to be $>95 \%$. SK-N-SH cells $\left(1 \times 10^{6}-3 \times 10^{6}\right.$ cells $\left./ \mathrm{ml}\right)$ were loaded with $3 \mathrm{mM}$ fura-2-AM in HBSS at $37^{\circ} \mathrm{C}$ for $20 \mathrm{~min}$. The cells were then washed once with HBSS and incubated for $1 \mathrm{~h}$ at $37^{\circ} \mathrm{C}$ in HBSS. The fluorescence of the cell suspension was monitored continuously using a F-4500 fluorescence spectrometer (Hitachi, Ltd., Tokyo, Japan) with excitation at 340 and $380 \mathrm{~nm}$ and emission at $500 \mathrm{~nm}$. Triton X-100 (0.1\%) and $10 \mathrm{mM}$ EDTA were added to obtain the maximum and minimum concentrations of calcium, respectively.

Cell lysis and protein quantification. SK-N-SH cells were seeded until an $80-90 \%$ confluence was reached and treated with ethanol $(0,50,100,200$ and $400 \mathrm{mM})$ and memantine $(4 \mu \mathrm{M})$ in $25-\mathrm{cm}^{2}$ tissue culture flasks. Cells were subsequently washed with Dulbecco's PBS (Biological Industries) and lysed on ice using radioimmunoprecipitation assay lysis buffer (Beyotime Institute of Biotechnology) containing $1 \mathrm{mM}$ phenylmethanesulfonyl fluoride (Beyotime Institute of Biotechnology). Lysates were harvested using cell scrapers, placed on ice for $30 \mathrm{~min}$ and then fragmented using an ultrasonicator. The lysates were centrifuged at $21,000 \mathrm{x} g$ for $15 \mathrm{~min}$ at $4^{\circ} \mathrm{C}$ and quantified for total proteins using a bicinchoninic acid protein assay kit (Beyotime Institute of Biotechnology).

Western blotting. Equal quantities of protein $(\sim 30 \mu \mathrm{g})$ were separated using $10 \%$ SDS-PAGE and the separated protein was transferred onto polyvinylidene fluoride membranes. The membranes were blocked for non-specific binding with $5 \%$ non-fat dry milk in Tris-buffered saline containing $0.05 \%$ Tween-20 (TBS-T) for $2 \mathrm{~h}$ at room temperature and then probed with primary antibodies overnight at $4^{\circ} \mathrm{C}$. The primary antibodies used were as follows: Rabbit anti-NR1 (1:500; cat. no. 13771-1-AP; ProteinTech Group, Inc., Chicago, IL, USA), rabbit anti-caspase-3 (1:200; cat. no. sc-98785; Santa Cruz Biotechnology, Inc.) and mouse anti- $\beta$-actin $(1: 1,000$; cat. no. TA-09; OriGene 
Technologies, Inc., Rockville, MD, USA). Subsequently, the blots were washed with TBS-T three times (5 mins/wash) and incubated with the corresponding peroxidase-conjugated goat anti-mouse or anti-rabbit secondary antibodies (1:10,000; cat. nos. E030110-02 and E030120-02; EarthOx Life Sciences, Millbrae, CA, USA) for $2 \mathrm{~h}$ at room temperature. Protein bands were detected with enhanced chemiluminescence reagent (EMD Millipore, Billerica, MA, Germany). Chemiluminescent signals were detected and analyzed by a Tanon 5500 Chemiluminescent Imaging system (Tanon Science and Technology Co., Ltd., Shanghai,China). Band densities were analyzed semi-quantitatively using Image J 1.6.0 software (National Institute of Health, Bethesda, MD, USA).

RNA extraction and reverse transcription-quantitative polymerase chain reaction $(R T-q P C R)$. Total RNA was extracted from cells using TRIzol ${ }^{\circledR}$ (Thermo Fisher Scientific, Inc., Waltham, MA, USA) and reverse transcribed into cDNA using a PrimeScript ${ }^{\mathrm{TM}}$ RT Reagent kit (Perfect Real Time; Takara Biotechnology Co., Ltd., Dalian, China). qPCR was performed using a SYBR ${ }^{\circledR}$ Premix Ex Taq ${ }^{\mathrm{TM}}$ II (TliRnaseH Plus; Takara Biotechnology Co., Ltd.) in a reaction volume of $20 \mu \mathrm{l}$ on an ABI 7500 Real-Time PCR system (Thermo Fisher Scientific, Inc.) using the following thermocycling conditions: $95^{\circ} \mathrm{C}$ for $30 \mathrm{sec}$, followed by 40 cycles of $95^{\circ} \mathrm{C}$ for $5 \mathrm{sec}$ and $60^{\circ} \mathrm{C}$ for $34 \mathrm{sec}, 95^{\circ} \mathrm{C}$ for $15 \mathrm{sec}, 60^{\circ} \mathrm{C}$ for $60 \mathrm{sec}$ and $95^{\circ} \mathrm{C}$ for $15 \mathrm{sec}$. The primer sequences used were as follows: $\beta$-actin forward, 5'-CTAACTTGCGCAGAAAACAAGAT-3' and reverse, 5'-TTCCTGTAACAACGCATCTCATA-3'; and NMDAR1 forward, 5'-CGCCAACTACAGCATCAT-3' and reverse, 5'-ATCGTCACAATCTTCAGTCT-3'. $\beta$-actin was used as the reference gene. The relative gene expression levels were represented as $\Delta \Delta$ quantification cycle $(\Delta \Delta \mathrm{Cq})$ and the fold change of gene expression was calculated via the $2^{-\Delta \Delta \mathrm{Cq}}$ method (30). Experiments were repeated in triplicate.

Statistical analysis. GraphPad Prism version 6 (GraphPad Software, Inc., La Jolla, CA, USA) was used for statistical analysis. Measurement data are expressed as the mean \pm standard error. One-way analysis of variance and Turkey's multiple comparisons test was used to compare differences between groups. The Wilcoxon rank sum test was used to compare differences among other types of data, including the percentage of apoptotic cells. $\mathrm{P}<0.05$ was considered to indicate a statistically significant difference.

\section{Results}

Daily ethanol volatilization. The ethanol volatilization per $24 \mathrm{~h}$ from $25-\mathrm{cm}^{2}$ flasks containing $5 \mathrm{ml}$ culture medium with ethanol are presented in the Table II.

Transfection efficiency for RNAi. The relative expression levels of NR1 protein in the untransfected group and control shRNA group were similar (Fig. 1A and B). Compared with the control group, the relative NR1 protein expression level in the NR1 shRNA group was significantly lower (Fig. 1A and B). These results suggested that RNAi was successful and cells transfected with NR1 shRNA and control shRNA were used for subsequent experiments.
Table II. Daily ethanol volatilization.

$\%$ daily ethanol volatilization

Groups

(mean \pm standard error)

$\begin{array}{ll}50 \mathrm{mM} \text { ethanol } & 19.57 \pm 1.37 \\ 100 \mathrm{mM} \text { ethanol } & 22.12 \pm 1.07 \\ 200 \mathrm{mM} \text { ethanol } & 24.57 \pm 0.60 \\ 400 \mathrm{mM} \text { ethanol } & 27.55 \pm 1.01\end{array}$

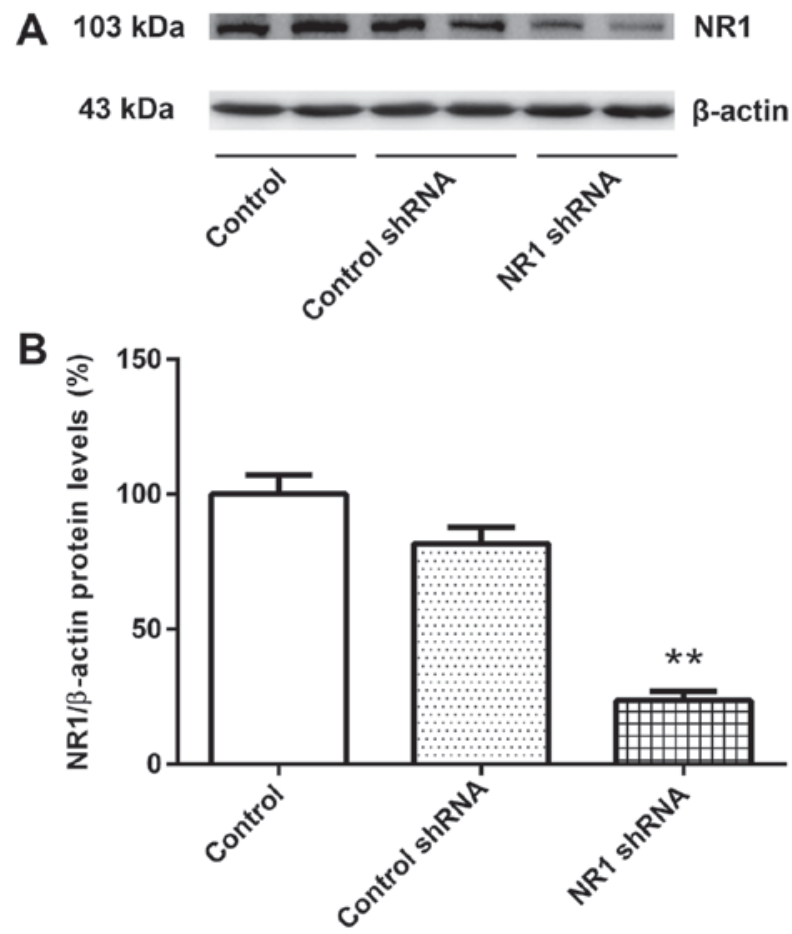

Figure 1. NR1 expression in SK-N-SH cells following chronic ethanol exposure. (A and B) Relative expression of NR1 in SK-N-SH cells is presented. All data were normalized to expression levels of $\beta$-actin. The relative expression levels of the NR1 protein in the control shRNA group was similar to the control group and the difference was not statistically significant. Conversely, the relative expression levels of the NR1 protein in the NR1 shRNA group was significantly lower than that in the control shRNA group. ${ }^{* *} \mathrm{P}<0.01$ vs. control shRNA group. Data are presented as the mean \pm standard error of the mean $(n=6)$. NRI, N-methyl-D-aspartate receptor subunit 1; shRNA, short hairpin RNA.

SK-N-SH cell activity decreases following chronic ethanol exposure and the effect is attenuated by memantine and downregulation of NR1 protein. SK-N-SH cells were treated with increasing concentrations of ethanol for 24-72 $\mathrm{h}$ and then cell viability was measured. Compared with the $24 \mathrm{~h} / 0 \mathrm{mM}$ ethanol group, cell viability decreased with increasing ethanol concentration and time (Fig. 2A). Compared with the control group, the cell viability of the ethanol groups was significantly lower. Compared with the ethanol group, the cell viability of the ethanol + memantine and ethanol + NR1 shRNA groups was significantly higher (Fig. 2B).

Apoptosis of SK-N-SH cells increases following chronic ethanol exposure and the effect is attenuated by memantine and downregulation of the NR1 protein. SK-N-SH cells were treated with increasing concentrations of ethanol for 24-72 h. 

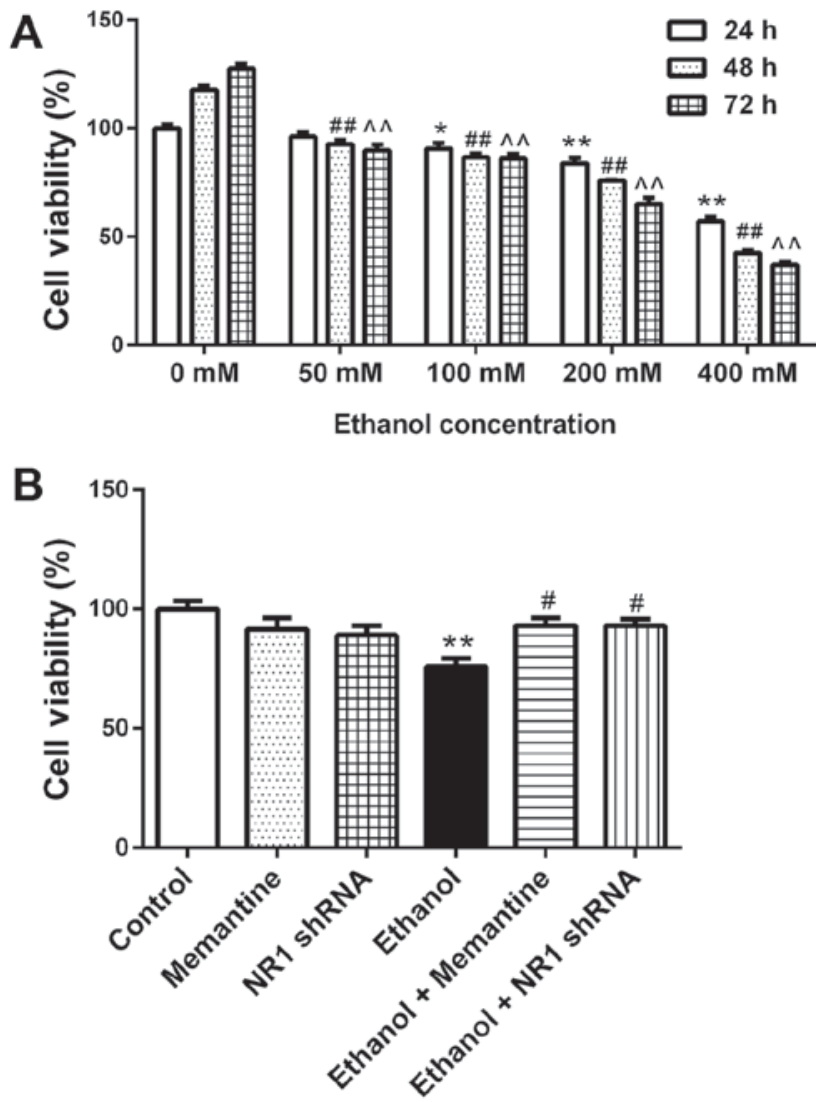

Figure 2. SK-N-SH cell viability following chronic ethanol exposure. (A) After exposure to ethanol, cell viability of SK-N-SH cells was lower compared with the $24 \mathrm{~h} / 0 \mathrm{mM}$ group, $48 \mathrm{~h} / 0 \mathrm{mM}$ group or $72 \mathrm{~h} / 0 \mathrm{mM}$ group. Cell viability decreased with increasing ethanol concentration and time. ${ }^{*} \mathrm{P}<0.05,{ }^{* *} \mathrm{P}<0.01$ vs. $24 \mathrm{~h} / 0 \mathrm{mM}$ group; ${ }^{\# \#} \mathrm{P}<0.01$ vs. $48 \mathrm{~h} / 0 \mathrm{mM}$ group; ${ }^{\wedge} \mathrm{P}<0.01$ vs. $72 \mathrm{~h} / 0 \mathrm{mM}$ group. (B) Compared with ethanol treatment group, the cell viability of ethanol + memantine group was significantly higher. Compared with the ethanol treatment group, the cell viability of the ethanol + NR1 shRNA-transfected group was significantly higher. ${ }^{* *} \mathrm{P}<0.01$ vs. ethanol group; ${ }^{*} \mathrm{P}<0.05$ vs. ethanol group. Data are presented as the mean \pm standard error of the mean $(n=5)$. NRI, N-methyl-D-aspartate receptor subunit 1; shRNA, short hairpin RNA.

Annexin V-FITC/PI double staining was used to detect the apoptotic rate of cells. Apoptotic cells included early apoptotic and late apoptotic cells (Fig. 3A and B; Table III). Compared with the $0 \mathrm{mM}$ ethanol groups at 24,48 and $72 \mathrm{~h}$, apoptosis was increased gradually with increasing ethanol concentration and time (Fig. 3A and B). Compared with the control group, apoptosis of the ethanol group was significantly higher. Compared with the ethanol group, apoptosis of the ethanol + memantine and ethanol + NR1 shRNA groups were significantly lower (Fig. 3C and D).

Memantine and downregulation of NR1 protein attenuates activation of the caspase-3 protein induced by ethanol. Western blotting revealed that the expression of cleaved caspase- 3 was higher in the ethanol group compared with the control group, whereas expression of cleaved caspase- 3 was significantly lower in the ethanol + memantine and ethanol + NR1 shRNA groups compared with the ethanol group (Fig. 4A and B).

$\mathrm{Ca}^{2+}$ concentrations in SK-N-SH cells increase following chronic ethanol exposure and the effect is attenuated by
Table III. Analysis of apoptosis in each group.

\begin{tabular}{lc}
\hline Groups & $\begin{array}{c}\text { \% cell apoptosis } \\
\text { (mean } \pm \text { standard error) }\end{array}$ \\
\hline $24 \mathrm{~h}$ & \\
Control & $2.66 \pm 0.19$ \\
$50 \mathrm{mM}$ ethanol & $3.72 \pm 0.13$ \\
$100 \mathrm{mM}$ ethanol & $4.60 \pm 0.25$ \\
$200 \mathrm{mM}$ ethanol & $12.54 \pm 0.58^{\mathrm{a}}$ \\
$400 \mathrm{mM}$ ethanol & $13.96 \pm 0.70^{\mathrm{a}}$ \\
$48 \mathrm{~h}$ & \\
Control & $3.72 \pm 0.30$ \\
Memantine & $3.22 \pm 0.27$ \\
NR1 shRNA & $4.50 \pm 0.25$ \\
$50 \mathrm{mM}$ ethanol & $4.36 \pm 0.42$ \\
$100 \mathrm{mM}$ ethanol & $15.06 \pm 1.08^{\mathrm{a}}$ \\
$100 \mathrm{mM}$ ethanol + memantine & $7.02 \pm 0.35^{\mathrm{b}}$ \\
$100 \mathrm{mM}$ ethanol + NR1 shRNA & $9.42 \pm 0.48^{\mathrm{b}}$ \\
$200 \mathrm{mM}$ ethanol & $25.04 \pm 1.18^{\mathrm{a}}$ \\
$400 \mathrm{mM}$ ethanol & $30.94 \pm 1.28^{\mathrm{a}}$ \\
$72 \mathrm{~h}$ & \\
Control & $3.92 \pm 0.55$ \\
$50 \mathrm{mM}$ ethanol & $7.04 \pm 0.51$ \\
$100 \mathrm{mM}$ ethanol & $22.00 \pm 1.59^{\mathrm{a}}$ \\
$200 \mathrm{mM}$ ethanol & $31.26 \pm 1.26^{\mathrm{a}}$ \\
$400 \mathrm{mM}$ ethanol & $38.32 \pm 1.62^{\mathrm{a}}$ \\
\hline
\end{tabular}

${ }^{\mathrm{a}} \mathrm{P}<0.01$ vs. control group; ${ }^{\mathrm{b}} \mathrm{P}<0.01$ vs. $100 \mathrm{mM}$ ethanol group.

memantine and downregulation of the NRI protein. Compared with the $0 \mathrm{mM}$ ethanol groups at 24-72 h, the mean intracellular $\mathrm{Ca}^{2+}$ concentration increased with increasing ethanol exposure concentration and time (Fig. 5A). Compared with the control group, the mean intracellular calcium concentration in the ethanol group was significantly higher. Compared with the ethanol group, the mean intracellular calcium concentration in the ethanol + memantine and ethanol + NR1 shRNA groups was significantly lower (Fig. 5B).

$N R 1$ protein and mRNA expression levels in $S K-N-S H$ cells increase following chronic ethanol exposure. SK-N-SH cells were treated with increasing concentrations of ethanol for 24-72 $\mathrm{h}$. Whole proteins were extracted for western blotting and the relative expression levels of the NR1 protein was detected. $\beta$-actin was used as the internal reference. Compared with the $0 \mathrm{mM}$ ethanol groups at 24-72 h, relative expression levels of the NR1 protein increased with increasing ethanol concentration and time (Fig. 6A-F). SK-N-SH cells were treated with increasing concentrations of ethanol for 24-72 h, and then the relative expression levels of NR1 mRNA were measured via RT-qPCR. Fig. 6G-I demonstrate that, compared with the $0 \mathrm{mM}$ ethanol groups at 24, 48 and $72 \mathrm{~h}$, the relative mRNA expression of NR1 increased gradually (excluding the $50 \mathrm{mM}$ group at $24 \mathrm{~h}$ ) with increasing ethanol concentration and time $(\mathrm{P}<0.05$; Fig. 6G-I). 

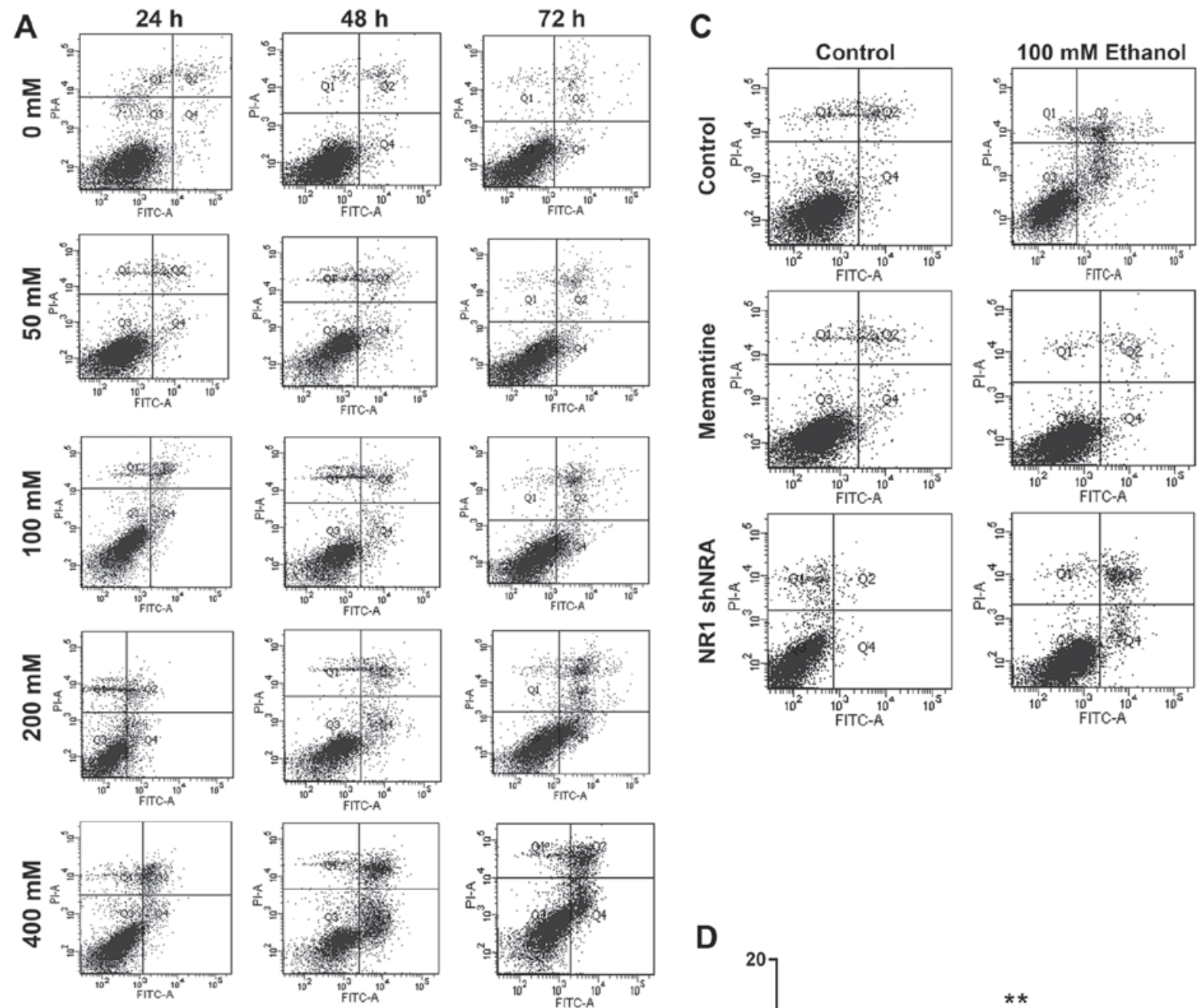

B
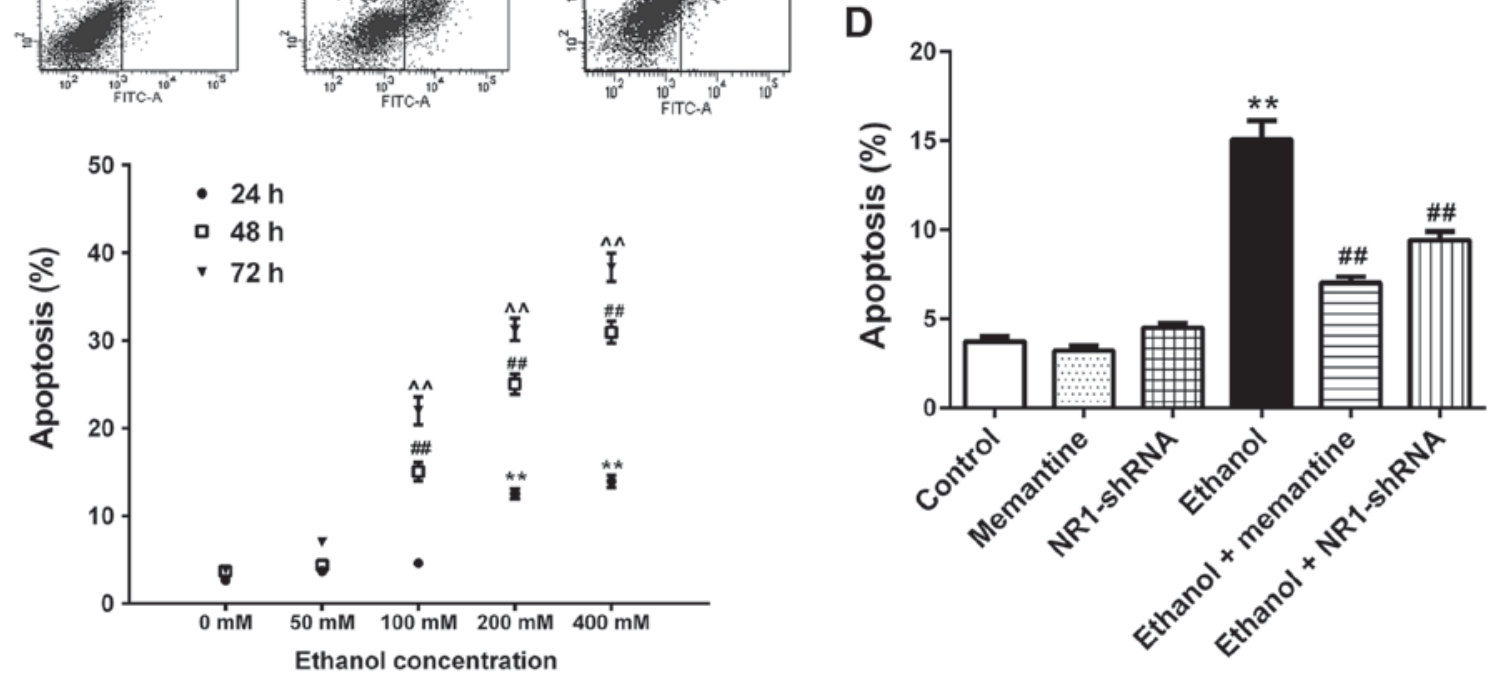

Figure 3. Cell apoptosis of SK-N-SH cells following chronic ethanol exposure. (A) Annexin V/PI double staining in SK-N-SH cells following chronic exposure to ethanol was detected by flow cytometry. The apoptotic rate of SK-N-SH cells were increased with increasing ethanol concentration and time. (B) Apoptosis rates were significantly increased with the increasing ethanol concentration and time. ${ }^{* *} \mathrm{P}<0.01 \mathrm{vs} .24 \mathrm{~h} / 0 \mathrm{mM}$ group; ${ }^{\# \prime \prime} \mathrm{P}<0.01 \mathrm{vs}$. $48 \mathrm{~h} / 0 \mathrm{mM}$ group; ${ }^{\wedge} \mathrm{P}<0.01 \mathrm{vs}$. $72 \mathrm{~h} / 0 \mathrm{mM}$ group, via the Wilcoxon rank sum test. (C) Memantine and NR1 shRNA decreased ethanol-induced cell apoptosis, as determined by Annexin V/PI double staining in SK-N-SH cells and flow cytometry. (D) Compared with the control group, the apoptotic rate of SK-N-SH cells in the 100 mM ethanol group was significantly higher. Compared with the ethanol group, the apoptotic rate of ethanol+memantine group was significantly lower. Compared with the ethanol group, the apoptotic rate of the ethanol + NR1 shRNA group was significantly lower, as determined by the Wilcoxon rank sum test. ** $<<0.01$ vs. control group; ${ }^{\# \#} \mathrm{P}<0.01$ vs. ethanol group. Data are presented as the mean \pm standard error of the mean $(n=5)$. NRI, N-methyl-D-aspartate receptor subunit 1 ; PI, propidium iodide; shRNA, short hairpin RNA.

\section{Discussion}

Previous studies have indicated that light, moderate to chronic or acute ethanol consumption may reduce neuron death and exhibit potentially neuroprotective effects $(31,32)$. But most studies have reported nerve cell degeneration, apoptosis and reduced densities in deceased individuals who succumb to chronic ethanol poisoning, as well as in experimental animals and cultured cells that undergo chronic ethanol exposure $(33,34)$. These findings indicated that ethanol induces 


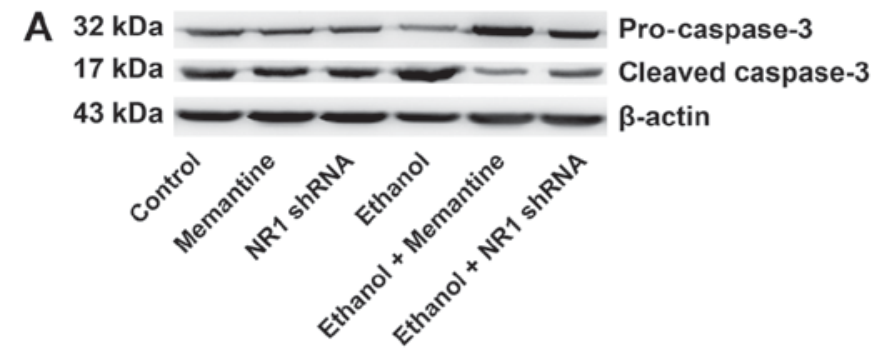

B

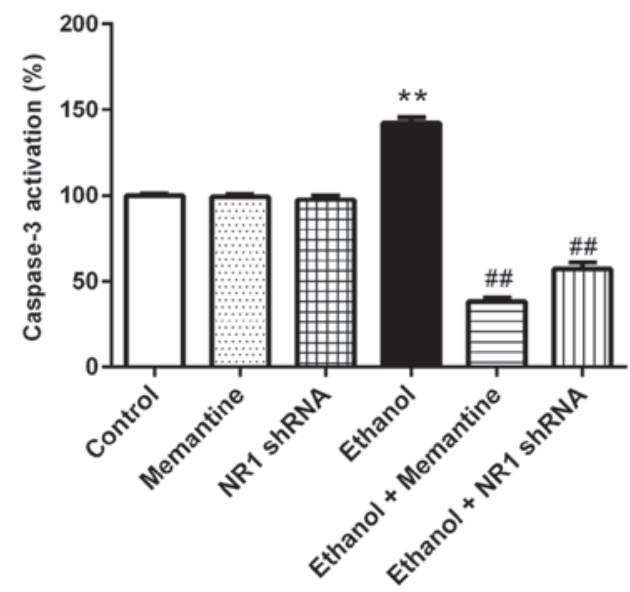

Figure 4. Effect of memantine and downregulation of the NR1 protein on cleaved caspase-3 expression in SK-N-SH cells caused by chronic ethanol exposure. (A) Compared with the control group, expression of cleaved caspase-3 protein increased in the ethanol group. Compared with the ethanol group, expression of cleaved caspase- 3 decreased in the ethanol + memantine group and ethanol + NR1 shRNA group. (B) Data normalized to $\beta$-actin levels demonstrated that the expression of cleaved caspase- 3 was higher in the ethanol group compared with the control group. Compared with the ethanol group, expression of cleaved caspase- 3 in ethanol + memantine and ethanol + NR1 shRNA groups were lower. ${ }^{* *} \mathrm{P}<0.01$ vs. control group; ${ }^{\# / t} \mathrm{P}<0.01$ vs. ethanol group. Data are presented as the mean \pm standard error of the mean $(n=6)$. NRI, N-methyl-D-aspartate receptor subunit 1; shRNA, short hairpin RNA.

nerve cell apoptosis via a number of mechanisms (35). It has previously been speculated that ethanol causes neuronal ATP metabolic disorders and calcium overload by decreasing cytochrome oxidase activity (36). Ethanol under the action of dehydrogenase and aldehyde dehydrogenase produce oxygen-free radicals that damage nerve cell DNA (37). As such, there is a strong interest in studies assessing ethanol neurotoxicity. However, due to the self-repair of cells and volatility of ethanol, the underlying mechanism of chronic ethanol exposure during apoptosis of cultured neurons in vitro remains unclear $(38,39)$. A previous study has suggested that the use of siRNAs to downregulate gene expression of NMDAR, IP3 receptor or sarco/endoplasmic reticulum calcium adenosine triphosphatase ATP-1 (SERCA1), or pre-administration of non-competitive NMDAR antagonist, memantine, inhibit intracellular $\mathrm{Ca}^{2+}$ release, thereby inhibiting the activation of caspase- 3 induced by isoflurane to control and reduce the occurrence of neuronal apoptosis (26). To the best of our knowledge, no previous studies have assessed the relationship between ethanol, NMDAR, intracellular $\mathrm{Ca}^{2+}$ and apoptosis. The present study therefore speculated that an abnormal intracellular $\mathrm{Ca}^{2+}$ transport pathway is of great importance in ethanol-induced neuronal cell apoptosis.

In the present study, SK-N-SH human neuroblastoma cells were used to examine whether ethanol-induced apoptosis was
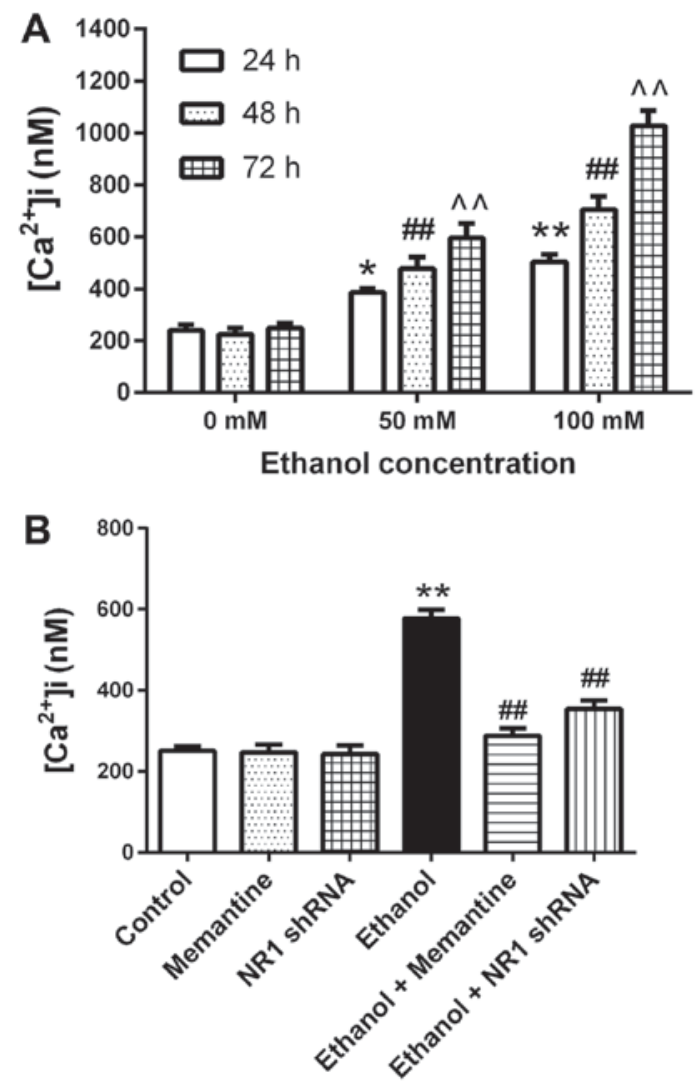

Figure 5. Mean intracellular calcium concentration following chronic ethanol exposure. (A) Mean intracellular calcium concentration was increased with increasing ethanol concentration and time. ${ }^{*} \mathrm{P}<0.05,{ }^{* * *} \mathrm{P}<0.01$ vs. $24 \mathrm{~h} / 0 \mathrm{mM}$ group; ${ }^{\# \#} \mathrm{P}<0.01$ vs. $48 \mathrm{~h} / 0 \mathrm{mM}$ group; ${ }^{\wedge} \mathrm{P}<0.01$ vs. $72 \mathrm{~h} / 0 \mathrm{mM}$ group. (B) Compared with the control group, the mean intracellular calcium concentration in SK-N-SH cells was significantly higher in the $100 \mathrm{mM}$ ethanol group $\left({ }^{* *} \mathrm{P}<0.01\right)$. Compared with the ethanol group, the intracellular mean calcium concentration in the ethanol + memantine group was significantly lower. Compared with the ethanol treatment group, the mean intracellular $\mathrm{Ca}^{2+}$ concentration in the ethanol + NR1 shRNA group was significantly lower. ${ }^{* *} \mathrm{P}<0.01$ vs. control group; ${ }^{\# \#} \mathrm{P}<0.01$ vs. ethanol group. Data are presented as the mean \pm standard error of the mean $(n=5)$. NRI, N-methyl-D-aspartate receptor subunit 1 ; shRNA, short hairpin RNA.

associated with NMDAR and intracellular calcium. SK-N-SH cells have been used in a previous study of neuronal cell apoptosis (40). Ethanol has strong volatility and many in vitro studies of ethanol exposure have investigated the effect of ethanol on cells cultured for a short period of time $(41,42)$. In a preliminary experiment, it was observed that due to its strong volatility, ethanol is unable to maintain relatively stable concentrations, which is accompanied by a compensatory response of self-protection by SK-N-SH cells. Therefore, the present study performed an ethanol volatilization experiment to ensure maintenance of chronic ethanol exposure.

Compared with the control group, an increase was observed in NR1 protein expression, mean intracellular $\mathrm{Ca}^{2+}$ concentration and apoptotic rate of SK-N-SH cells, and a decrease was observed in in cell viability. It was also demonstrated that with greater exposure concentration and duration of ethanol to SK-N-SH cells, the degree of cell damage was increased. These results indicated successful establishment of the chronic ethanol exposure model in SK-N-SH cells and confirmed that expression of the NR1 protein in SK-N-SH cells was increased by chronic ethanol exposure. As the expression of 
A
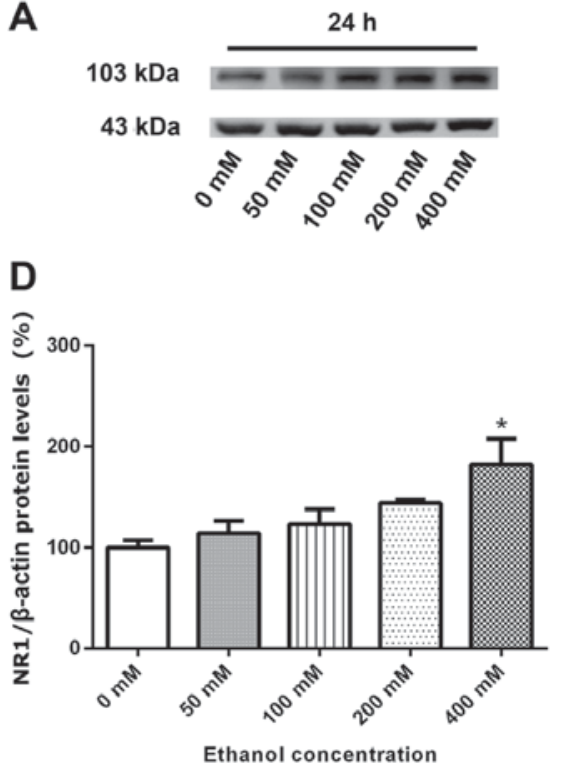

G

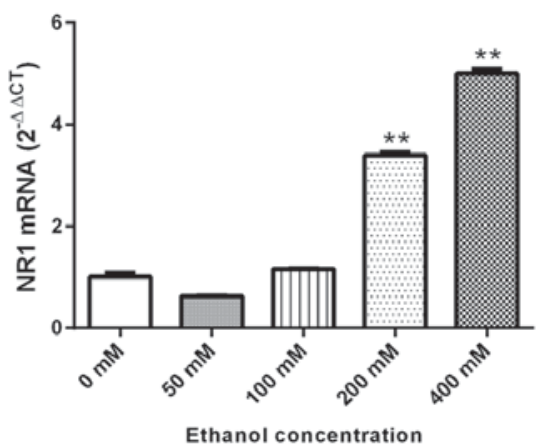

B

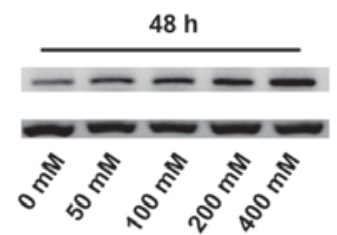

E

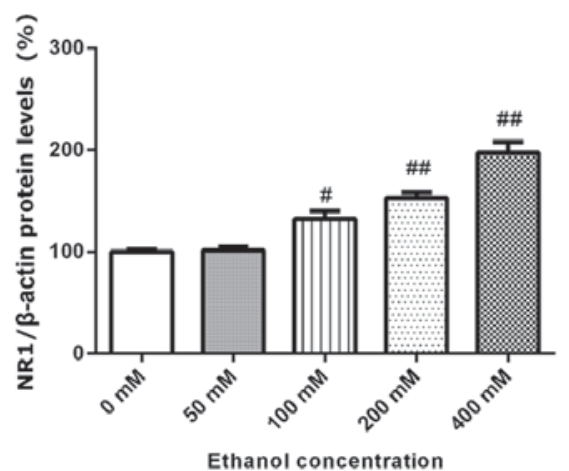

H

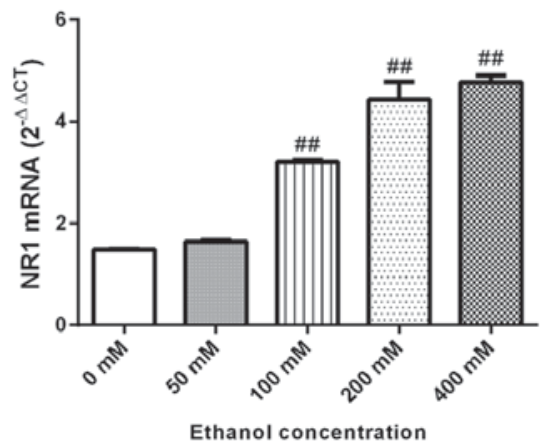

C

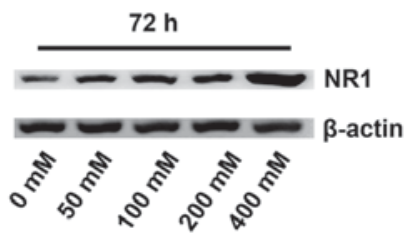

F

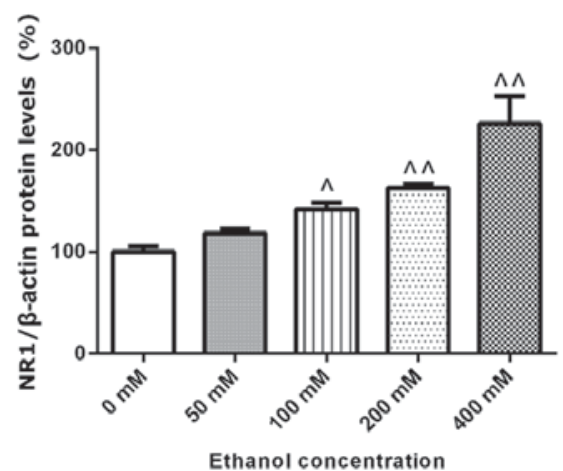

I

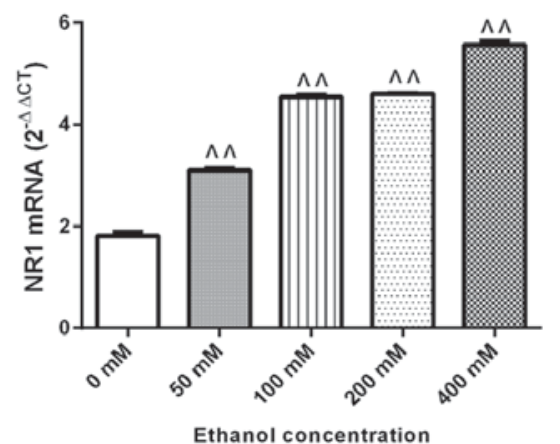

Figure 6. Protein and mRNA expression of NR1 increases in SK-N-SH cells following chronic ethanol exposure. (A-F) Expression of the NR1 protein in SK-N-SH cells treated with ethanol were significantly higher than that in 24,48 and $72 \mathrm{~h} / 0 \mathrm{mM}$ groups. NRI expression increased with increasing ethanol concentration and time. Data were normalized to $\beta$-actin. (G-I) mRNA expression of NR1 increased with increasing ethanol concentration and time compared with 24,48 and $72 \mathrm{~h} / 0 \mathrm{mM}$ groups. ${ }^{*} \mathrm{P}<0.05,{ }^{* *} \mathrm{P}<0.01$ vs. $24 \mathrm{~h} / 0 \mathrm{mM}$ group; ${ }^{\#} \mathrm{P}<0.05,{ }^{\# \#} \mathrm{P}<0.01 \mathrm{vs} .48 \mathrm{~h} / 0 \mathrm{mM}$ group; ${ }^{\wedge} \mathrm{P}<0.05,{ }^{\wedge} \mathrm{P}<0.01$ vs. $72 \mathrm{~h} / 0 \mathrm{mM}$ group. Data are presented as the mean \pm standard error of the mean $(n=6)$. NRI, N-methyl-D-aspartate receptor subunit 1.

NR1 protein increased, the intracellular calcium concentration also increased. This suggested that the effects of chronic ethanol exposure may be mediated via the NMDAR-mediated calcium transport pathway to increase the intracellular calcium concentration in SK-N-SH cells. High intracellular calcium may activate apoptosis and reduce cell viability and proliferation.

To support the above speculation, SK-N-SH cells were treated with $100 \mathrm{mM}$ ethanol for $48 \mathrm{~h}$ and then with the noncompetitive NMDAR antagonist, memantine, at $4 \mu \mathrm{M}$. In addition, the expression levels of the NR1 gene in SK-N-SH cells was downregulated by NR1 shRNA. The results revealed an increase in the mean $\mathrm{Ca}^{2+}$ concentration, of cleaved caspase- 3 and apoptosis, and a decrease in cell viability of the ethanol group compared with the control group. Compared with the ethanol group, there were decreases in the mean intracellular $\mathrm{Ca}^{2+}$ concentration, expression of cleaved caspase-3 and apoptotic rate, and an increase in the cell viability of the ethanol + memantine and ethanol + NR1 shRNA groups.

However, the present study also observed that shRNA-mediated downregulation of NR1 protein expression and non-competitive antagonism by memantine did not completely reverse the increase in the intracellular $\mathrm{Ca}^{2+}$ concentration, increase in apoptosis, or the decrease of cell viability and other neurotoxic effects caused by chronic ethanol exposure in neuronal cells. These results suggested that the neurotoxicity caused by chronic ethanol exposure is not limited to its effect on NMDAR, but also involves a variety of mechanisms working together. The mechanism of cellular damage caused by chronic ethanol exposure to neuronal cells is complex. Therefore, a follow-up study of IP3R (43), SERCA1 (44) and other proteins associated with $\mathrm{Ca}^{2+}$ transport pathway and other signaling pathways associated with neuronal cell damage, will be investigated in future studies.

In conclusion, chronic ethanol exposure inhibited neuronal cell viability and caused apoptosis of neuronal SK-N-SH cells, and the extent of damage in SK-N-SH cells was associated with ethanol exposure concentration and duration. In addition, chronic ethanol exposure induced expression of NMDAR and increased the concentration of intracellular $\mathrm{Ca}^{2+}$ in SK-N-SH cells, resulting in apoptosis. Memantine had a protective effect against damage in SK-N-SH cells. The results of the present study indicate that the application of memantine may provide a novel strategy in the treatment of alcoholic dementia. However, 
future studies should be conducted in vivo using animals to assess the effects of ethanol on the brain, including in learning and memory.

\section{Acknowledgements}

The authors of the present study thank Mr. M. Arico from Liwen Bianji, Edanz Group China (www.liwenbianji.cn/ac), for editing the English of this manuscript.

\section{Funding}

The present study was supported by the National Natural Science Foundation of China (grant no. 81172904), Natural Science Foundation of Liaoning Province, China (grant no. 201102299), Shenyang Scientific and Technological Plan, China (grant no. F11-264-1-67) and the Program for Medical Teaching and Science Research of China Medical University, the 13th Five-Year Plan (grant no. YDJK2016034).

\section{Availability of data and materials}

The analyzed data sets generated during the present study are available from the corresponding author on reasonable request.

\section{Authors' contributions}

The work presented here was carried out in collaboration between all authors. GZ and RZ collaborated to design the study. HW, XW, YL, HY and JC the designed methods and experiments. HW, CW, GX and JY carried out the laboratory experiments. CF and PW analyzed the data. HW, XW and YL drafted the manuscript. XW, RZ and GZ provided critical revision and contributed to the interpretation of findings. All authors have contributed to, read and approved the manuscript.

\section{Ethics approval and consent to participate}

Not applicable.

\section{Consent for publication}

Not applicable.

\section{Competing interests}

The authors declare that they have no competing interests.

\section{References}

1. Masaki T, Mochizuki H,Matsushita S, Yokoyama A, Kamakura K and Higuchi S: Association of aldehyde dehydrogenase-2 polymorphism with alcoholic polyneuropathy in humans. Neurosci Lett 363: 288-290, 2004.

2. Johansson S, Ekström TJ, Marinova Z, Okvist A, Sheedy D, Garrick T, Harper C, Kuzmin A, Yakovleva T and Bakalkin G: Dysregulation of cell death machinery in the prefrontal cortex of human alcoholics. Int J Neuropsychopharmacol 12: 109-115, 2009.

3. McVicker BL, Tuma DJ, Kharbanda KK, Kubik JL and Casey CA: Effect of chronic ethanol administration on the in vitro production of proinflammatory cytokines by rat kupffer cells in the presence of apoptotic cells. Alcohol Clin Exp Res 31: $122-129,2007$
4. Crews F, Nixon K, Kim D, Joseph J, Shukitt-Hale B, Qin L, and Zou J: BHT blocks NF-kappaB activation and ethanol-induced brain damage. Alcohol Clin Exp Res 30: 1938-1949, 2006.

5. Wang Y, Seitz HK and Wang X: Moderate alcohol consumption aggravates high-fat diet induced steatohepatitis in rats. Alcohol Clin Exp Res 34: 567-573, 2010.

6. Akane K, Kojima S, Mak TW, Shiku H and Suzuki H: $\mathrm{CD} 8{ }^{+} \mathrm{CD} 122^{+} \mathrm{CD} 49 \mathrm{dlow}$ regulatory $\mathrm{T}$ cells maintain $\mathrm{T}$-cell homeostasis by killing activated T cells via Fas/FasL-mediated cytotoxicity. Proc Natl Acad Sci USA 113: 2460-2465, 2016.

7. Jeong JB, Choi J, Lou Z, Jiang X and Lee S: Patchouli alcohol, an essential oil of Pogostemoncablin, exhibits anti-tumorigenic activity in human colorectal cancer cells. Int Immunopharmacol 16: 184-190, 2013.

8. Zou J and Crews F: Induction of innate immune gene expression cascades in brain slice cultures by ethanol: Key role of NF- $\mathrm{BB}$ and proinflammatory cytokines. Alcohol Clin Exp Res 34: 777-789, 2010

9. Baykara B, Micili SC, Tugyan K, Tekmen I, Bagriyanik H, Sonmez U, Sonmez A, Oktay G, Yener N and Ozbal S: The protective effects of carnosine in alcohol-induced hepatic injury in rats. Toxicol Ind Health 30: 25-32, 2014.

10. Bolnick JM, Karana R, Chiang PJ, Kilburn BA, Romero R, Diamond MP, Smith SM and Armant DR: Apoptosis of alcohol-exposed human placental cytotrophoblast cells is downstream of intracellular calcium signaling. Alcohol Clin Exp Res 38: 1646-1653, 2014.

11. Grynkiewicz G, Poenie M and Tsien RY: A new generation of $\mathrm{Ca}^{2+}$ indicators with greatly improved fluorescence properties. J Biol Chem 260: 3440-3450, 1985.

12. La Rovere RM, Roest G, Bultynck G and Parys JB: Intracellular $\mathrm{Ca}(2+)$ signaling and $\mathrm{Ca}(2+)$ microdomains in the control of cell survival, apoptosis and autophagy. Cell Calcium 60: 74-87, 2016.

13. MacDermott AB, Mayer ML, Westbrook GL, Smith SJ and Barker JL: NMDA-receptor activation increases cytoplasmic calcium concentration in cultured spinal cord neurones. Nature 321: 519-522, 1986.

14. Finch EA, Turner TJ and Goldin SM: Calcium as a coagonist of inositol 1,4,5-trisphosphate-induced calcium release. Science 252: 443-446, 1991.

15. Bezprozvanny I, Watras J and Ehrlich BE: Bell-shaped calcium-response curves of Ins $(1,4,5) \mathrm{P} 3$ - and calcium-gated channels from endoplasmic reticulum of cerebellum. Nature 351: 751-754, 1991.

16. Flatscher-Bader $\mathrm{T}$ and Wilce PA: Impact of alcohol abuse on protein expression of midkineand excitatory amino acid transporter 1 in the human prefrontal cortex. Alcohol Clin Exp Res 32: 1849-1858, 2008.

17. Sattler R and Tymianski M: Molecular mechanisms of calcium-dependent excitotoxicity. J Mol Med (Berl) 78: 3-13, 2000.

18. Pérez-Otaño I and Ehlers MD: Homeostatic plasticity and NMDA receptor trafficking. Trends Neurosci 28: 229-238, 2005.

19. Lau CG and Zukin RS: NMDA receptor trafficking in synaptic plasticity and neuropsychiatric disorders. Nat Rev Neurosci 8: 413-426, 2007.

20. Glue P and Nutt D: Overexcitement and disinhibition. Dynamic neurotransmitter interactions in alcohol withdrawal. Br J Psychiatry 157: 491-499, 1990.

21. Addolorato G, Mirijello A, Leggio L, Ferrulli A and Landolfi R: Management of alcohol dependence in patients with liver disease. CNS Drugs 27: 287-299, 2013.

22. Petralia RS, Wang YX, Hua F, Yi Z, Zhou A, Ge L, Stephenson FA and Wenthold RJ: Corrigendum to organization of NMDA receptors at extrasynaptic locations. Neuroscience 167: 68-87, 2010.

23. Vicini S, Wang JF, Li JH, Zhu WJ, Wang YH, Luo JH, Wolfe BB and Grayson DR: Functional and pharmacological differences between recombinant N-methyl-D-aspartate receptors. J Neurophysiol 79: 555-566, 1998.

24. Chiu J, Brien JF, Wu P, Eubanks JH, Zhang L and Reynolds JN: Chronic ethanol exposure alters MK-801 binding sites in the cerebral cortex of the near-term fetal guinea pig. Alcohol 17: 215-221, 1999.

25. Devaud LL, Morrow AL and Nguyen UT: Ovariectomy has minimal effects on neuroadaptations associated with ethanol dependence in female rats. Neurochem Int 37: 433-442, 2000.

26. Zhang G, Dong Y, Zhang B, Ichinose F, Wu X, Culley DJ, Crosby G, Tanzi RE and Xie Z: Isoflurane-induced caspase-3 activation is dependent on cytosolic calcium and can be attenuated by memantine. J Neurosci 28: 4551-4560, 2008. 
27. Wasfi IA, Al-Awadhi AH, Al-Hatali ZN, Al-Rayami FJ and Al Katheeri NA: Rapid and sensitive static headspace gas chromatography-mass spectrometry method for the analysis of ethanol and abused inhalants in blood. J Chromatogr B Analyt Technol Biomed Life Sci 799: 331-336, 2004.

28. Joshi R, Tawfik A, Edeh N, McCloud V, Looney S, Lewis J, Hsu S and Ogbureke KU: Dentin sialophosphoprotein (DSPP) gene-silencing inhibits key tumorigenic activities in human ora cancer cell line, OSC2. PLoS One 5: e13974, 2010.

29. Wang P, Wang Q, Yang L, Qin QL and Wu YJ: Characterization of lysophosphatidylcholine-induced changes of intracellular calcium in Drosophila S2 cells. Life Sci 131: 57-62, 2015.

30. Livak KJ and Schmittgen TD: Analysis of relative gene expression data using real-time quantitative PCR and the 2(-Delta Delta C(T)) method. Methods 25: 402-408, 2001.

31. Qi SH, Liu Y, Hao LY, Guan QH, Gu YH, Zhang J, Yan H, Wang M and Zhang GY: Neuroprotection of ethanol against ischemia/reperfusion-induced brain injury through decreasing c-Jun N-terminal kinase 3 (JNK3) activation by enhancing GABA release. Neuroscience 167: 1125-1137, 2010

32. Nazam Ansari M, Bhandari U, Islam F and Tripathi CD: Evaluation of antioxidant and neuroprotective effect of ethanolic extract of Embelia ribes Burm in focal cerebral ischemia/ reperfusion-induced oxidative stress in rats. Fundam Clin Pharmacol 22: 305-314, 2008.

33. Hwang DW, Givens B and Nishijima I: Ethanol-induced developmental neurodegeneration in secretin receptor-deficient mice. Neuroreport 20: 698-701, 2009.

34. Oliveira-da-Silva A, Vieira FB, Cristina-Rodrigues F, Filgueiras CC, Manhães AC and Abreu-Villaça Y: Increased apoptosis and reduced neuronal and glial densities in the hippocampus due to nicotine and ethanol exposure in adolescent mice. Int J Dev Neurosci 27: 539-548, 2009.

35. Harper C: The neuropathology of alcohol-related brain damage. Alcohol Alcohol 44: 136-140, 2009.
36. Mooney SM and Miller MW: Effects of prenatal exposure to ethanol on the expression of bcl-2, bax and caspase 3 in the developing rat cerebral cortex and thalamus. Brain Res 911: 71-81, 2001 .

37. Brooks PJ: Brain atrophy and neuronal loss in alcoholism: A role for DNA damage? Neurochem Int 37: 403-412, 2000.

38. Kumral A, Tugyan K, Gonenc S, Genc K, Genc S, Sonmez U, Yilmaz O, Duman N, Uysal N and Ozkan H: Protective effects of erythropoietin against ethanol-induced apoptotic neurodegenaration and oxidative stress in the developing C57BL/ 6 mouse brain. Brain Res Dev Brain Res 160: 146-156, 2005.

39. Mooney SM and Miller MW: Nerve growth factor neuroprotection of ethanol-induced neuronal death in rat cerebral cortex is age dependent. Neuroscience 149: 372-381, 2007.

40. Li Y, Li R, Zhu S, Zhou R, Wang L, DU J, Wang Y, Zhou B and Mai L: Cordycepin induces apoptosis and autophagy in human neuroblastoma SK-N-SH and BE(2)-M17 cells. Oncol Lett 9: 2541-2547, 2015

41. Hurley MM, Martin D and Raisz LG: Changes in ethanol concentration during incubation in multiwell tissue culture trays. Proc Soc Exp Biol Med 186: 139-141, 1987.

42. Borgs P, Way DL, Witte MH and Witte CL: Effective stabilization of ethanol levels in multiple-well tissue culture plates. Alcohol 10: 31-35, 1993

43. Hanson CJ, Bootman MD and Roderick HL: Cell signalling: IP3 receptors channel calcium into cell death. Curr Biol 14: R933-R935, 2004.

44. MacLennan DH, Rice WJ and Green NM: The mechanism of $\mathrm{Ca}^{2+}$ transport by sarco(endo)plasmic reticulum $\mathrm{Ca}^{2+}$-ATPases. J Biol Chem 272: 28815-28818, 1997. International (CC BY-NC-ND 4.0) License. 